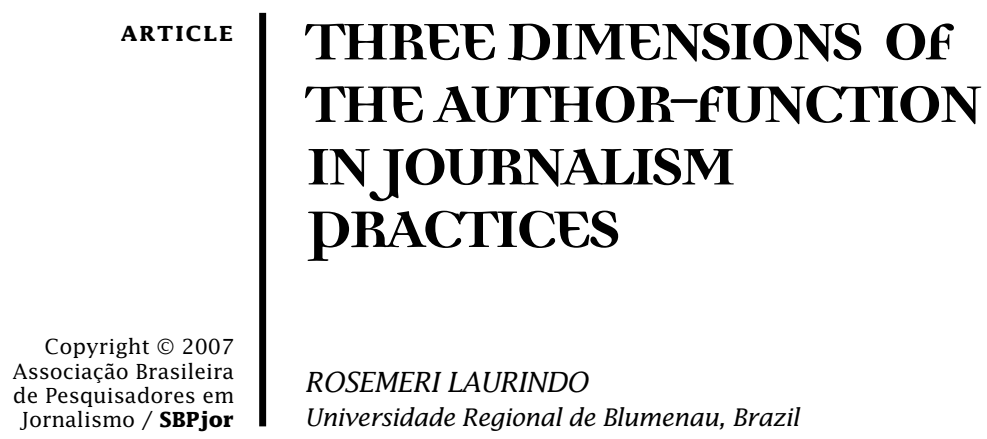

ABSTRACT The following communication sums up the doctorate thesis "The Three Dimensions (singular, particular and universal) - of the author-function in the Construction of the Typologies of Journalism: Journalist-Author and Brand-Author", presented by the researcher to the Department of Communication Science of the School of Social and Human Sciences of the New University of Lisbon, in November 2005. The thesis discusses what the author is in journalism and proposes the dimensioning of the author function from two typologies: journalist-author and brand-author. The former articulates the categories: singular, particular and universal, while the latter is a prisoner of the hegemonic logic of the institutional and organizational powers, asphyxiating the possibility of a universal grasp of the singular. In a world controlled by the brand kingdom, singularity survives, despite everything. It is the way that remains for journalism as a social means for apprehension of reality, always requiring specific and transforming education.

KEY-WORDS journalism, author-function, journalist-author, brand-author, universal-singular

\title{
Introduction
}

This study proposes a reflection on the author in journalism, a subject that presents itself within a wide disciplinary universe, involving literature, language philosophy, linguistics, sociology, sociolinguistics, among others, in such a way that the approach we intend becomes conditioned to an interdisciplinary process whose methodological constitution has been one of the major challenges for the consolidation of the journalistic field. To fit the theme, we 
first discuss the role that the author has assumed in the history of the "art of letters"'. Then, when reducing the object of study, we face the following difficulty: the authorial problematic does not itself constitute a fundamental field for journalistic studies. The verification of the importance of this problematic, with the necessary outlines, constituted one of the central objectives of the doctorate thesis that we presented under the title "The three dimensions (singularparticular-universal) of the author-function in the construction of the typologies of journalism: journalist-author and brand-author" in the Department of Communication Science of the School of Social and Human Sciences of the New University of Lisbon and of which we present a synthesis in this study.

Our methodological approach starts with the author-function, in a modified apprehension of the proposal by Michel Foucault (1992), as the Frenchman did not contemplate the specificity of the journalistic discursive field. Moreover, we go further than the discursive modalities foreseen by Foucault, passing through the Brazilian researcher Eni Orlandi $(1988,1996,1999)$, who reflected about discourses that, at first view, seemed disconnected from the author-function.

Nevertheless, the most important theoretical affiliation of the thesis is linked to the epistemology of journalism as a social means of knowledge crystallized in the singular (CENRO FILHO, 1987). From that basis, we developed the problem of the relations among singularity, particularity and universality and perceived the author in journalism, linked to the three mentioned categories in a dialectical articulation that conceives the human being as a social-historical product. Therefore, the premises of Genro Filho, based on a dialectical historical materialist epistemology, must be taken into consideration. In Brazil, Genro Filho was responsible for a prophylactic proposition of Journalism Theory.

The focus that we put on the singular as the central category for the author in journalism, deals with the same dimension that is present since the first thesis on journalism that is known (1690, according PEUCER, 2000), which determines as newspaper subjects singular things or events. It is the singular of the philosophical discussion that has Aristotelian registers, but which when considered here will have the same sense as the one proposed by Genro Filho, which is based on the Marxist method where the singularity constructs itself in the universality and vice versa, not as antagonistic poles but as dimensions 
mediated by particularity. The important thing for journalism is seeing that the interrelation among singular, particular and universal is a part of the author-function in journalism. And, taking the last years under consideration, a trend emerges in relation to the study of journalistic hypothetic authorships, and a body of laws is shaped on authorship in journalism, co-authorship, collective authorship, etc, justifying the need for theoretical immersion in the subject.

\section{The concept of author}

Preoccupation with the paternity of the work is an old problem that can be found since the critics of the myths in classical philosophy. With the questionings of Plato/Socrates to writing, the author (of knowledge) gains one of the first statements of value (on the contrary) in Phedro, in the dialogue that talks about the forgetfulness that writing provokes in the soul of the one who learns, as long as the person ceases to exercise memory. We have, then, the "death" of author announced two millenniums before Barthes.' The link of a great dedication to the master - Socrates - could be an explanation for the (self-) deprecation that Plato makes about writing in Phedro². Ironically, it is by the hand of Plato that the memory of Socrates becomes perennial, constituting, with the Dialogues, a work of complex authorship.

It can be perceived that historically, there are great moments of rupture which question the authorial position. About the mythical meeting - in the dialogue of Socrates and Phedro - of the god Thoth ${ }^{3}$ and the Egyptian king, where the former presented the invention of writing, the platonic narration leaves some interrogations: eventually, which author is it talking about? About the god Thoth? About the narrators of the myth? About the one embodied in Socrates and/or his interlocutors? About the signature of Plato? This field of questioning can be enlarged and seems to make clear that the whole reflection that was constructed throughout the millenniums of intertextual games, since the assumed dialogue between Phedro and Socrates, applies to the present writing (the same as this article) because of some kind of authorial capacity and investment, renowned as being from Plato, whose referential nature will certainly be a problem of architextual order in eternal incompleteness. Technological changes will provoke the evolution of the materials for the fixation of writing. We could say, 
today, that the models of authorial figures are developing outlines while they materialize themselves in successive supports (tablets, papyrus, parchment, paper, the press, the virtual environment)

A complex literary variety fuels the discussion on authorship, problematic that needs to be approached in accordance with specific discursive functions. We shall take the journalistic discourse.

Within journalism, the author, as an instance of subject effacement, works as a mechanism that, when absent, serves for the deresponsibilization of the journalist. It is not that authorship constitutes an exclusive condition of responsibility, but it is the discloser of a certain degree of majority. As if he who sings "showed himself" more responsible for that than he who writes. Otherwise, he would remain hidden under "anonymity".

In order to understand the perspective of the author in the specific approach of studies in the field of journalism, it is important to verify some aspects of the studies developed within this field, and that is why we will make a point of the situation from the productive routines, because of the following reasons.

\section{Productive routines}

The studies of the influence of journalistic working routines on the criteria of newsworthiness was emphasized in Brazil in the 90's, when it constituted a field of specific studies about journalism, to particularize investigations that previously remained on very wide lines of the media sphere in general, mixing journalism, entertainment, publicity, etc.

About the routines, there was an expansion of a significant set of investigations performed by American sociologists since the 70's. In Brazil, this line of research developed in works that assumed the particular perspective of the productive routines or of the so-called newsmaking. In Portugal, Traquina (1993) organized a work with a translation of original studies in the English language, spread widely through the Brazilian academic medium, intensifying the adoption of studies of the routines.

Tuchmann (1978) establishes a milestone for the researchers who start to consider the news as an element of the social construction of reality, underlining the prevalence of the routines that the journalists create to define what the news is. Tuchman developed a theoretical focus together with a consistent empirical approach, built up 
following the productive routines. His investigations are considered milestones in the field of the professional sociology of journalism. The journalist is recognized as the subject of the discourse that he produces and transmitter of knowledge about reality. The researcher follows that proposal, considering the journalist as the professional that has professional worries, but not as an individual with personal preferences, issues which, according to Tuchman, would be more appropriate to Psychology.

Simplifying individuality as a problem of Psychology, the author sees this issue as a fragmentary possibility of reality, not considering that the subject, even immersed in the institution and in the professional culture that guides him, carries inside him what is peculiar and singular to him, and that, despite the professional rules that the organization or the community to which he belongs state, can certainly emerge in the journalistic discourse. It is not the subject of this work to understand the subject as a brain to be violated or as an individual disconnected from the social environment. On the contrary, when saying "subject of journalism", we are clearly nominating the social-individual, conditioned, but not determined, by the cultural, historical and social soup in which he is immersed, also capable then of intervening in reality. To understand the narrow borders between professional groups and journalistic organizations, it is impossible to go further without considering that subjectivity is built in the dialectic relation between the individual and the society with its institutions, and the mediations for language take place exactly along this encounter, which is the basis of subjectivity itself.

Tuchman remarks that the coordinator - executive director of the editorial staff, editor-in-chief, or sector chief - leads the negotiation in relation to what is important to be treated as news. However, if it is certain that the daily editorial meetings of director and editors determine the important items of a piece of news, it is relevant to also observe that those editors concentrate on a story that has already been worked out through the view of a reporter, and that, the higher his degree of autonomy and experience, the higher will be his capacity to build up a piece of news that will satisfy the demands that he knows will be made in the meeting with the chiefs. It is not only a satisfaction to fit the patterns, but from the same knowledge of those patterns, as a strategy that permits finding the best way to adapt some content that, in another way, could be not accepted in the meeting. 
Even thinking only about the meeting, within four walls, there are journalists who with their own particularities develop a role connected to the professional practice, not always consensual, as in the case of accepting or not the objectivity that for Tuchman constitutes a series of routine procedures, such as the use of quotes, significance levels, legal precedents, verification and discussion of sources, exposition to conflicts, complementary evidence, among others

It is as unreal understanding the individual in an isolated way as it is considering society without individuals. It is not possible to suppose a logical comprehension that could imagine the individual disconnected from the social milieu. The counterpoint that we present understands that the relation individual-society is basic to the relation individualgeneric aspect that carries on the historical objectives of the human generations:

They are observations that must be appropriated by the individual, in order to control the system of references of the context in which he lives and, then, direct himself as an active and participant subject of the changes within that context. However in order to understand it in its multiple relations, it is necessary to consider that the whole process between the individual (the singular) and humankind (the universal) takes place in the relation that the individual has with society (the particular) (OLIVEIRA, 2005:28-29)

In order to get deeper into that complexity we would need to notice the productive routines of the journalism without the aspect not taken into account by Tuchman, which is the role of the individual. Or better, it is important to verify in this exclusion a fragmentary conception that affects the sociological process itself since it is a mistake not to question the dimension of the social-individual, as if thinking of the individual, would be retaining it in a bell jar without social contact, as if it could be possible through some kind of discipline.

\section{Responsibility and social function}

Journalism consolidated itself to be an object of study during the $X X$ century, frequently immersed in the communicational universe in a wider way and more recently involved in the so-called mediatic field, where it is common to see the journalism area being confused with programs from the entertainment sphere or from the publicity 
field. However, classifications as the one by Roman Jackobson for the functions of language demonstrate the specificity of the journalistic discourse, which distinguishes itself from discursive types such as the poetic, epistolary, historic, publicity, religious, legal, among others, despite the hybrid possibilities of the discursive genres.

Motta (2003) verifies that there is a decrease of the interference of the journalist in the propaganda of the news, which would be occurring, for instance, in on-line journalism. With a more compact and infographic language, it is possible to observe a crisis related to the more and more fragmented day-to-day, composing "traps of incommunication" (MOTTA, 2003:163). The author advocates the reestablishment of the particular place of words as a task of the journalist. "Wording the reality": a task for those who intend to communicate. Neither the studies about journalism, nor the journalist must be satisfied in knowing only why this or that is being published. They ought to understand for which reason they do it. In other words, what is the function that they must perform in society?

In journalism we will try to demonstrate, based on the author-function, that the one who writes must take charge of the text. A dialogue is more and more enhanced when opened by journalist-authors who show their photos, short biographies, a necessity of authorship that contemporary communication has been asking for. It is the call for responsibility.

\section{The author-function in journalism}

In journalism the concept of author must be understood as a function of the discourse that arises in the relation with the reader. In the studies in the journalistic field it is frequently asked what turns an event into news. There is a search for objective patterns to attain dimensions of subjective perspective and vice-versa. Defining methodological parameters to cross these aspects is an immeasurable problem. Among the possible perspectives in contemporary journalistic discourse, it is important not to lose from sight that it is a field of authorial relation, where the dimensions of sense construction go through exchanges between author and reader, independently of where this partnership of discursive reading is (interviewed-interviewer, ruler-reporter, reporter-editor, newspaper and newspaper's reader, architect of the information - producer, etc).

We come close to the notion of author brought by Foucault, with complementary interpretation, to open the problem for the study field 
in journalism. It is important to emphasize the questionings of the philosopher: the author's name denotes in the same way the different texts that he publishes with his name or nickname, published during life or death, in a draft or in notes, with and without corrections? Foucault introduces into the issue the aspect of the multiple possible languages of an individual and consequently the impossibility of a correct and homogeneous unit.

The possible differences in relation to the author's name occur, according to Foucault, to assure a classifying function: "a certain name permits regrouping a certain number of texts, delimiting them, selecting them, comparing them to other texts.", characterizing a discursive way of being. It can be concluded that some texts are provided with the author-function and others are not.

We can add the concepts of singular, particular and universal to impregnate the author-function, since they express logical connections of thinking. Genro Filho (1987) selected those categories for a theory of journalism. For him, in journalism singularity is an "arriving point that coincides with the transcending of the particular and of the universal that survive as meanings in the body of news and under the patronage of the singular".

In the condition of author-function we would be transforming now the founder author of Foucault into a condition of fundamental author of journalism, in perspectives not taken into consideration by the Frenchman. When presenting a very particular use of the categories of singular, particular and universal we do not do it without having previously recognized that the relation in such dimension sustains itself on a philosophical and logical basis whose dimension arose with the Greeks. But it will be in the transcendence of the singular in the direction of the universal, passing through the intermediation of the particular dimension, that we will have the specific pattern of journalistic knowledge, which expresses itself therefore from the dialectic among singularity, particularity and universality. We work, finally, with typological constructions, in such a way that they will present themselves not as ultimate objectives of the journalistic function but only as a means to permit a deeper knowledge of brands still to be better questioned.

Involving discipline, organization and unit, the authorship outlines the dispersion of the subject within the text. The authorship detains, this way, the subjectivity of the conscious-author. As a function of the subject, in a specific social practice - the journalistic one - the 
author-function is, therefore, a discursive-function of the subject, based on the relation with the reader, where finally the mediation of the singular to the universal emerges. We emphasize the authorfunction as a grouping principle necessary for any discourse.

We introduce the authorial function as a transverse theme to the genre divisions. We believe that through the understanding of this function, we will be able to understand the different interfaces of contemporaneous journalism. It is in the exercise of the authorial function that the issues of ethics in the journalism, for example, and also the linguistic ones will be outlined.

It is valuable to consider technical progress as political foundation, as was underlined by Benjamin (1936), when talking about the author seeing himself as a producer. Summarizing, the journalist will not be an author only if his position in the process of news production is not noticed. If this happens, not because of that the problem will be attributed to the particular essence of journalism, as well as the corrupt politicians do not represent the reason for politics.

The visibility and self-conscience of the subject, expressed in its authorial dimension, is what will permit the "control" that a discourse needs, especially the journalistic one, which has its sense built up in the relation with the social milieu or, in other words, in the close relation with the receivers, that ask for identification. If we understand that the subject extends itself in the discourse, but guides itself in the text, we can stop to ask for an authorial code that could transcend its dimensions, a new unit.

\section{Journalist-author and brand-author among the singular, particular and universal dimensions}

We propose the associations among singularity, particularity and universality as a dimensioning that respects the contingence of the authorial phenomena in journalism. Like the interpenetration among past, present and future (in time), of height, width and depth (in space) and of the solid, liquid and gaseous states (in matter), that compose the universe, we reflect about the authorial problematic from the facets in reciprocal conversion.

It is important to consider that in 1690, in what was the first authorial thesis in journalism of which there is a record, Peucer (2000) presents the patterns of singular, particular and universal as components of the 
continuous line that orders the succession of historical events, and that the matter of newspapers would be singular things of different kinds or classes. It is surprising to conclude that after intense journalistic changes during these more than three hundred years after the publication of Peucer's study, we can still review the specificity that journalism preserves, regardless of its changes.

Peucer uses the expression "Periodistika", noted by the Brazilian translator, Paulo Rocha Dias, as the oldest in the branch of Communication and Information Science. In the difference he makes between news compilers and historians, Peucer launches epistemological issues about which up to now the thinkers of journalist still debate.

We will develop now the author-function with the unfolding of the universal, particular and singular dimensions, from some approaches, through which the categories were taken into consideration, reciprocally linked and conditioned, in such a way as to compose journalistic mediation.

UNIVERSAL - Universality marks a wider level of conception for journalism, on which the guidelines for the author-function are based, with rules shared by professionals of different countries. The journalistic field is composed by professional, technical and business rules, processes and related publics. The universal is the unus (only one in Latin) for everybody, the general, the context. It is the effort to reinforce concepts that could be socialized by international communities, for example, to establish dialogues and also to enable the establishment of standard practices and universal rights.

The universal category, when bringing elements of professional tradition, that transcend national borders, helps with the establishment of an international community in the journalistic field. It is the collective dimension in its extension. But if this collective is not perceived as a result of the dialectic relation among singularparticular-universal it is not appropriate for the discussion that is proposed here. And this is a very common confusion, which implies transferring wrongly the relation singular-universal to the individualcollective antagonism, as if society were the humankind category itself. The difficulty mentioned leads to the mistake of restricting the life of a singular being as isolated from the social totality. Both dimensions (singular and universal) are based on social mediations that promote the traffic of these complementary spheres, without, 
therefore, disconnecting from one of them.

PARTICULAR - On this level, the cultural, time and place reasons concentrate, promoting the social mediations that will point out the kind of traffic between singular and universal. What is particular and peculiar, lies in a transitory dimension. It is, for instance, the dimension that explains differences of Brazilian journalistic practice different from Portuguese journalistic practice, despite pursuing a universal praxis, which would only achieve its plenitude at the moment in which the generic aspect as humankind could say more to journalists than the objectivities historically materialized that reference him as Portuguese or Brazilian. The most institutionalized journalistic field is the one of the relation with society. A crossing dimension, as a filter, goes from the singular to the universal.

It is in that intermediary zone that the different authorial functions will be built, as the class interests that are built in capitalist society are disguised as universal, without having any sense of humankind development.

SINGULAR - It is on the singular level that the authorial-function, linked to a body-to-body relation with life, is stressed. It is the dimension that performs the confrontation between the individual and the social environment, composing the subject. In a world impregnated with information, the author-function on its singular level becomes one of the essential conditions of the necessary referential aspect. Singularity is an experience performed in a relatively direct way (GENRO FILHO, 1987:160). The place of insertion of the journalist- author, in a more sensitive abstract dimension, it cannot be conceived independently from the particular and from the universal. Journalistic language concentrates in the singular all other dimensions. This is the level from which it is possible to think about corporeity, where everything is felt.

There is governance of intentionality when the author is conscious of the subjectivity that lies beneath discourse and mediation. The journalist does not break free from being the subject, but the degree of this consciousness is different in each relation that is created. That is why the author-function on its singular level is the specific consciousness taken of the journalism, the only one that involves 
the particular and universal in relations built according to the understanding of the subject about such connections.

The inseparable nature of the categories and the relationship with journalistic writing is an effort to focus the tension between the theory and the practice of the aspects that involve journalism. Such observations require a hypothesis of identification of the place of such encounter, which constitutes journalistic praxis.

\section{The journalist-author}

We shall reflect now on singularity, particularity and universality in order to understand how these three dimensions could be expressed according to the author-function that organizes the journalistic discourse so as to give account of a knowledge which was crystallized in the singular. We will build up typologies that classify the communicational intention mentioned, without neglecting, according to Charaudeau (2004) that "the communicative functions do not necessarily correspond to the communicative intentions of the speakers" and that the same discourse can associate a range of functions, which are outlined according to the relations that are established between the author and the reader.

The ideal kind characterizes the professional behavior inserted into organizations. The journalist-author function expresses the singular dimension of the testimony, with the respective connections that explain the relations of the individual with the world. Priority is given to eyewitness or vigilant testimony, which can pass from the singular to the universal. We classify as journalist-author that subject who performs the authorial function in its dimension, which is more adapted to the epistemology of journalism as an expression of knowledge through the mediated experience and not as the experience itself.

The journalist-author function is the answer that we find in our search for the author in the journalistic field, understood according to an order that guides itself through the epistemology designed by Genro Filho, as we announced before. Regarding this theoretical consideration, it is worthwhile remembering that the journalist-author that we mention has its basis in the singular, since it was designed in the continuous alliance about which Genro Filho talks when he proposes the singular as the central category of a journalistic theory.

When we talk about the journalist-author it is implicit that reality cannot be changed in a phenomenon destitute of historical, social and 
cultural connections. When we classify the journalist-author it is not possible to confuse social relations with relations among individuals. When we talk about the journalist-author, we reinforce once more the singular category as a guideline for the epistemology of journalism since Peucer, but we draw attention to the interrelation about which Genro Filho warned.

Genro Filho even points out that it is the historical rise of journalism that gives life to knowledge in the direction of the singular, always surely as the "crystallization point that collects the movements of the particularity and universality that converge to each other". The singular not understood in its necessary relation with the particular and universal, cannot explain the journalist-author that we propose.

The counterpoint seems necessary to avoid singularity mixing with disconnected events that do not conform to the premises of this reasoning. The events of the singular dimension that live inside the author expressed here are flows of reality in which subjectivity and ideology guide themselves according to outlines aiming without obstacles at the always present possibility of change and transcendence of a conservative order.

The journalist-author is the subject that produces and is produced by the object, which is able to transcend the conditions imposed on it. It would be sufficient to observe the critical news that overflows common sense in the functional relation with the reproduction of society. To do so, we insist, there must be a minimum of particular contextualization with the singular that will make the news into a way of awareness, constituting or not a critical apprehension of reality. At the moment in which the interrelations express themselves, the world which opens up is that of the journalist-author who gives the reader his chance to agree or disagree, because what opens up to reading will be a field of connections guided by the co-authorial conditions. Reinforcing: the journalist-author presents an experience mediated by connections among singular-particular-universal and not the experience (or event) itself. Everybody gets changed by this kind of experience.

\section{Brand-author}

The function of the brand-author is the maximum expression of the industrial process of authorship. The place of the brand-author is the territory of a journalistic culture that explains itself according 
to the logic of the market. In the empire of consumption it is not only the information-product that is wanted anymore. There must be something else based on the brand, result of the contamination between Journalism and Publicity.

Marshall (2003) calls "transgenic journalism" that which grows from the inoculation of the publicity aesthetic. The enthroning of publicity in the journalistic language has the permission of the brand-author. The conception of brand congregates the main signs of Publicity in order to promote mutations in journalism. "Brought to bay, journalism is subduing itself to the system, subverting altogether its concepts, values, patterns, and positioning." (MARSHALL, 2003:24).

The brand-author is therefore an expression of the present society in journalism. It is the author-function submerged in the particularity of a system in which performance is a commitment and in which singularity is a reference adrift from its connections, with a false perception of culture and life, as if reality would have been born like it is today.

The result is an identification that must be ratified according to the present patterns, dictated by the brand culture. No authority or important personality gives an interview to just anyone. It must be given to a journalist who works for Globo, Folha de São Paulo. It must have a griffe. In the past the professional link of a journalist was also important although there was not the habit of signing the news as it is done nowadays. The problem is that nowadays the entailment corrupts the textual aspect, where the surface is worth more than the depth. The difference is that society is presently guided by the cultural values of brand, where the brand is the measurement of things, the engine of society, the culture in effect.

Throughout a way of brand construction, the journalist can build himself up as a brand, becoming a brand of the brand: "someone from Globo". Then the values built do not have any relation with the referential that is sought in the journalistic discourse as a social pattern of knowledge crystallized in the singular.

What can be seen is the non-performance of a dialectical order among the singular-particular-universal dimensions in the brandauthor function. In this case there is professional behavior that leads to the adaptation of the individual to the society and that, taking into consideration the capitalist hegemony, establishes not a universal reader-author relation, but a brand consumer-author one.

The place of brand-author has been consolidated, so subjects are guided by the logic of consumption, in a bluntness of personality 
that does away with the possibility of transcendence of singularity, limited to details of the market, masked as universal values.

\section{Conclusions}

Defining the three dimensions of the author-function in journalism is a contribution that we add to the particular way Foucault approached the discourses that contained the author-function. We have adopted the notion of author beyond the statute of originality and could observe that the authorial sense of writing in proclaiming "I exist" can be lost in nominal indications that are not always clear; however, as Orlandi remarks, there will always be a hypothesis of authorship attribution. It is an understanding based on the author-function.

We have stated a new issue with regard to singular as a sensitive dimension of journalism: in fact, what is sensitive without the senses - touch, smell, hearing, vision and taste? How can one explore the sensitive without the body-to-body contact with life, except through the singular(s) as point(s) of the inseparability between theory and practice, in such a way that "theorizing" and "doing" join themselves through the experience of the sensitive, where thinking and corporeity are translated into language attitude?

It is from the singular that it is possible to conclude the universal (general) and particular (common), dimensions that articulate themselves in a logical relation questioned since the Greeks. The philosophical thinking about induction, that is moving in the direction of the universal from singular data, explains our human necessity that the authors of journalism touch for on us in what is situated in the most different places which our senses do not reach. Journalism is the virtual possibility of experiencing everything, with the strictness of a referential based on social agreements through the dialectic of the singular-particular-universal. The body/identity of someone else is necessary, someone who was "there" to articulate the exposition of reality with the singular, the particular and the universal, a dialectical body that could perform the transition to the universal, without enslavement to private interests. The mediating function must then be performed with consciousness, becoming in this way explicit.

At a moment in which we see the consolidation of the laws that guide the rights of the author in journalism, it is impossible to prevent the author-function from becoming part of the sphere of researchers and professionals who think about the journalistic doing/thinking/ 
legislating, especially when the liberalization of the profession of the journalist tends to transcend the labor laws. Discussing the authorfunction from this perspective is necessary for promoting the debate on the social function of journalism.

We build up in this way the concepts of journalist-author and brandauthor. The former would take shape in the condition of a concrete articulator of the singular, particular and universal categories, and the latter, without losing the idea that it has an author-function, would practice journalism as a prisoner of the hegemonic logic of the organizational and institutional powers that surround it, suffocating the possibility of a universal range of the singular.

Within this context, what continue to constitute the journalism are the relations between those functions (brand-author and journalist-author). This is verified with the questioning of the author, in the individual and collective relations that compose its configurations, taking into consideration the social mediations synthesized in the individual that bring him to this or that degree of universality. In a world ruled by the reign of brands, nevertheless singularity survives. This is the way that remains open for journalism as a social pattern of awareness of reality, always requiring a specific and transforming pattern.

\section{NOTES}

1 The text "La mort de I'Auteur", by Roland Barthes, 1968, is paradigmatic in studies of authorship.

2 Socrates narrates the encounter with the Egyptian god Thoth presenting the invention of writing to the king Tamuz who in turn comments about the knowledge to be spread not only through memory anymore: “... Hão-de parecer homens de saber, embora não passem de ignorantes em muitas matérias e tornar-se-ão, por conseqüência, sábios imaginários, em vez de verdadeiros sábios!". (PLATÃO,2000:121)

3 In the famous Egyptian picture of the weighting of the dead heart we can see Thoth beside the balance noting what happens. It is the first representation that I know of a reporter. So he looks like the first "reporter" of human history. 


\section{BIBLIOGRAPHY}

BABO, Maria Augusta. ‘Da intertextualidade: a citação’. In Revista de Comunicação e Linguagens, Centro e Estudos de Comunicação e Linguagens da Universidade Nova de Lisboa, 1986:113-119.

BABO, Maria Augusta. 'Apresentação'. In Revista de Comunicação e Linguagens, Centro e Estudos de Comunicação e Linguagens da Universidade Nova de Lisboa, 1990: 7-13.

BABO, Maria Augusta. A Escrita do Livro. Lisbon: Verbo, 1993.

BAKHTIN, Mikhail. Estética da Criação Verbal. São Paulo: Martins Fontes, 2000. (Original: Estetika Slovesnogo Tvortchestva, Moscow).

BAKHTINE, Mihail. 'O enunciado no romance'. Translation by Isabel Gonçalves and Margarida Barahona. In Lingüística e Literatura. Lisbon: Editions 70, 251-264. (Original: Linguistique et Littérature - Revista Langages, no 12, s/d.).

BARTHES, Roland. La mort de l'Auteur. Oeuvres Complètes. Tome II, 1966-1973. Paris: Seuil, November/1994, 491-495. (The first publication of the text was in the magazine Matéia V).

BARTHES, Roland. Le Plaisir du texte. Oeuvres Complétes. Tome II, 1966-1973. Paris: Seuil, November, 1493-1532. Translation to Portuguese by Maria Margarida Barahona, Lisbon: Edições 70, s/d.

BENJAMIN, Walter. 'O narrador'. In BENJAMIN, Walter. Sobre Arte, Técnica, Linguagem e Política. Lisbon: Relógio D’Água Editores, 1992.

BONINI, Adair.'Reflexões em torno de um conceito psicolingüístico de tipo de texto'. In D.E.L.T.A., vol. 15 nº 2, 1999: 301-318. http:// www.scielo.br/pdf/delta/v15n2/a04v15n2.pdf

BREED, Warren. 'Controlo social na redação. Uma análise funcional'. In: TRAQUINA, Nelson. Jornalismo: Questões, Teorias e "Estórias". Lisbon: Vega, 1993:152-166.

BRUNN, Alain. L'auteur. Paris:Flammarion Corpus-lettres, 2001.

BUESCU, Helena Carvalhão. Em busca do autor perdido - histórias, concepções, teorias. Lisbon: Edições Cosmos, 1998.

CHALABY, Jean. 'O Jornalismo como invenção anglo-americana. Comparação entre o desenvolvimento do jornalismo francês e anglo americano ( 1830-1920)'. In Revista Media \& Jornalismo, Coimbra: Edições Minerva Coimbra, nº 3, ano 2, 2003. 
CHILLÓN, Albert. Literatura y Periodismo.Una tradición de relaciones promiscuas. Bellaterra: Universitat Autònoma de Barcelona: Servei de Publicaciones, 1999.

CHRISTOFE, Lilian. Intertextualidade e Plágio: questões de linguagem e autoria. Doctorate thesis for the Lingüistics course at Universidade Estadual de Campinas, 1996.

CUNHA, Tito Cardoso e. Universal singular- filosofia e biografia na obra de J.-P. Sartre. Lisbon: Fim de século Edições Lda, 1997.

DULONG, Renaud. Le Témoin Oculaire. Les conditions sociales de I'attestation personnelle. Paris: Éditions de L'École des Hautes Études en Sciences Sociales, 1998.

ECO, Umberto. Sobre a literatura. Rio de Janeiro/São Paulo: Editora Record, 2003.

FERNANDES, Noélia Maria da Mata. A autoria e o Hipertexto. Masters theses in Comunicação, Cultura e Tecnologias da Informação, Departamento de Sociologia, Lisbon, 1999.

FOUCAULT, Michel. O que é um autor? ( $3^{\mathrm{a}}$ ed.). Translation by António Fernando Cascais and Eduardo Cordeiro. Lisboa: Vega, Passagens, 1992.

FOUCAULT, Michel. A Ordem do Discurso. Translation: Laura Fraga de Almeida Sampaio. Lisbon: Relógio D’Água Editores, 1997.

GENRO FILHO, Adelmo. O segredo da pirâmide - para uma teoria marxista do jornalismo. Porto Alegre: Tchê! Editora Ltda, 1987.

HAACK, Susan. Filosofia das Lógicas. São Paulo: Editora UNESP, 2002, 91-111.

MARSHALL, Leandro.O jornalismo na era da publicidade. São Paulo Summus, 2003.

MOTTA, Luiz G. ‘Crise no paradigma do jornalismo: mas qual paradigma?'. In Pauta Geral, Ano 10, nº 5, Salvador: Calandra, 2003: 137-173.

OLIVEIRA, Betty. 'A dialética do singular-particular-universal'. In ABRANTES, Angelo Antonio et alii (orgs.). Método histórico-social na psicologia social. Petrópolis: Vozes, 2005: 25-51.

ORLANDI, Eni P. Análise de discurso: princípios e procedimentos. (4 ${ }^{\mathrm{a}}$ ed.) Campinas: Pontes, 2002.

ORLANDI, Eni Pulcinelli. Discurso e Leitura. (2 ${ }^{\mathrm{a}}$ ed.). Campinas: Cortez, edit. da Unicamp, 1993. 
ORLANDI, Eni Puccineli. Interpretação - autoria, leitura e efeitos do trabalho simbólico. Petrópolis: Vozes, 1996.

PARK, Robert E. 'A notícia como forma de conhecimento: um capítulo da sociologia do conhecimento' In STEINBERG, Charles (org.). Meios de Comunicação de Massa. São Paulo: Cultrix, 1972.

PAULI, Evaldo. Enciclopédia Simpozio. <http://www.simpozio.ufsc.br> accessed in 2004.

PEUCER, Tobias. De relationibus novellis. Leipzig: (Doctorate in Journalism), University of Leipzig, 1690. Translation by Paulo da Rocha Dias to Portuguese from the original in Revista Comunicação \& Sociedade, $n^{\circ} 33,1^{\text {st }}$ semester, 2000; republished in: Revista Estudos em Jornalismo e Mídia, Florianóplis: Insular, 2004, 13-30.

PLATÃO. Fedro ou Da Beleza. Translation and notes by Pinharanda Gomes, $6^{\text {th }}$ edition. Lisbon: Guimarães Editores, 2000.

SARTRE, Jean-Paul. Que é a Literatura? São Paulo: Editora Ática, 1989. SCHUDSON, Michael. 'The sociology of news production revisited'. In CURRAN, James \& GUREVITCH, Michael ( eds) Mass media and society. New York: Edward Arnold, 1992: 141-159.

SOARES, Edvaldo. Fundamentos de lógica: elementos de lógica formal e teoria da argumentação. São Paulo: Atlas, 2003: 23-37.

TODOROV, Tzvetan. Prefácio in BAKHTIN, Mikhail. Estética da Criação Verbal. São Paulo: Fontes, 2000: 19.

TODOROV, Tzvetan. Les genres du discours. Paris: Seuil, 1978.

TODOROV, 'Tzvetan.'Os Limites D’Egar Poe’. In TODOROV, Tzvetan. Os Gêneros do Discurso. Lisbon: Edições 70, s/d.

TRAQUINA, Nelson. Teorias de Jornalismo. A tribo jornalística - uma comunidade interpretativa transnacional. Florianópolis: Insular, 2005.

TRAQUINA, Nelson. O Estudo de Jornalismo no Século XX. São Leopoldo: Editora Unisinos, 2001.

TRAQUINA, Nelson. Jornalismo: Questões, Teorias e “Estórias". Lisbon: Vega, 1993.

TRAQUINA, Nelson. 'As notícias'. In: TRAQUINA, Nelson. Jornalismo: Questões, Teorias e “Estórias”. Lisbon: Vega, 1993:167-176.

TRAQUINA, Nelson. O que é Jornalismo. Lisbon: Quimera, 2002.

TUCHMAN, Gaye. Making News - A Study in the Construction of Reality. 
The Free Press, 1978. (Spanish version entitled: "La producción de la noticia - estudio sobre la construcción de la realidad", translation by Héctor Borrat, Barcelona: Editorial Gustavo Gili S.A).

TUCHMAN, Gaye. 'A objetividade como ritual estratégico: uma análise das noções de objetividade do jornalista'. In TRAQUINA, Nelson. Jornalismo: Questões, Teorias e "Estórias". Lisbon: Vega, 1993: 74-90.

TUCHMAN, Gaye. 'Professionalism as an Agent of Legitimation'. In Journal of Communication, vol. 28 (2), 1978.

Roseméri Laurindo is a Doctor in Communication Sciences (Journalism Specialization) from the New University of Lisbon, Master in Communication and Contemporary Culture from the Federal University of Bahia and Graduate in Journalism from the Federal University of Santa Catarina. She is a professor in the courses of Publicity and Advertising and Veterinary Medicine at the Regional University of Blumenau and of Journalism at the University for the Development of the Upper Itajai Valley. She has acted as a journalist in companies in the States of Santa Catarina, Alagoas and Bahia. 